
\title{
\& Research Square \\ Delimiting cryptic species in a shark with a low dispersal capability
}

Fahmi Fahmi ( $\nabla$ fahmi@lipi.go.id)

Indonesian Institute of Sciences https://orcid.org/0000-0003-3199-7467

lan Tibbetts

The University of Queensland

Mike Bennett

The University of Queensland

Chris Dudgeon

The University of Queensland

Research article

Keywords: Speciation, Species complex, Chiloscyllium punctatum, SNPs

Posted Date: December 18th, 2020

DOI: https://doi.org/10.21203/rs.3.rs-130246/v1

License: () (i) This work is licensed under a Creative Commons Attribution 4.0 International License.

Read Full License 


\section{Abstract}

\section{Background}

Delimiting cryptic species in elasmobranchs is a major challenge in modern taxonomy due the lack of available phenotypic features. Employing stand-alone genetics in splitting a cryptic species may prove problematic for further studies and for implementing conservation management. In this study, we examined mitochondrial DNA and genome-wide nuclear single nucleotide polymorphisms (SNPS) in the brown-banded bambooshark, Chiloscyllium punctatum to evaluate potential cryptic species and the species-population boundary in the group.

\section{Results}

Our results found four operational taxonomic units (OTUs) within C. punctatum from the Indo-Australian region. Each OTU can be interpreted differently depending on available supporting information. Similarly, we confirmed that comprehensive sampling over the species' geographic distribution was essential to determine the boundary between population and cryptic species.

\section{Conclusion}

We provide suggestions about what should be considered prior to split cryptic species and the designation of new species.

\section{Background}

The development of genetic and genomic studies has substantially influenced how species are defined taxonomically, with a shift from traditional taxonomy based on morphological and biological characters to one that includes or entirely relies on DNA-evidence (e.g. (1)). While the necessity for phylogenetic support in defining a species is the subject of debate, many journals require phylogenetic analyses in the description of new taxa (2). Advanced DNA sequencing has revealed species complexes and cryptic species previously assumed to be subspecies or populations of a single species through traditional taxonomic analysis (3-5). In evolutionary theory, species complexes are considered recently diverged from evolving metapopulations $(3,6)$. As an ongoing process of speciation, morphological differentiation may develop later due to local adaptation to new environments $(3,4)$. Cryptic species may be present within a complex when morphologically indistinguishable individuals are revealed to be genetically distinct (6-8). While there are disparities in the definition of cryptic species in terms of their biology, they provide challenges for taxonomic and evolutionary studies (9). For instance, the discovery of cryptic species in what was previously considered a single wide-ranging species raises questions whether geographically-structured populations can be differentiated from different species within the same region, leading to taxonomic confusion $(10,11)$. A reliance on genetic evidence alone to split a species complex into two or more new species presents wildlife managers and ecologists with challenges as morphological features that facilitate visual discrimination are absent (12-14). A lack of field-based 
identification may confound determination of a species' conservation status, and management strategies that might be relevant for that species $(6,15,16)$.

Cryptic species are common in many groups of taxa and various habitats, including in marine environments $(4,6,17)$. In elasmobranchs, the number of recognised cryptic species has increased substantially within the last decade, primarily due to a large, multi-taxa, phylogenetic study of mitochondrial NADH2 sequences (18). Several putative cryptic species have been identified with most originating from areas of high geographic complexity, and in taxa with low dispersal ability $(18,19)$. The use of genome-wide approaches alongside mitochondrial markers has improved the ability to identify cryptic diversity of elasmobranchs (e.g. in mobulids (20)).

In this study, we examined the brown-banded bambooshark, Chiloscyllium punctatum, a species distributed in near-shore environments within the Indian and the Western Pacific Oceans (21-25) (Fig. 1), and the most commonly caught shark in coastal fisheries in Southeast Asia (26). Previous genetic and morphological studies have suggested that $C$. punctatum contains two cryptic species $(18,27)$. However, the genetic study only included a few sampling locations with uneven sample sizes and large geographic breaks, likely under-representing the species' genetic diversity within the region [17]. Here we use genomewide nuclear single nucleotide polymorphisms (SNPs) along with mitochondrial DNA lineages to assess potential cryptic speciation within an extensive, previously un-sampled area within the Indonesian archipelago, and to evaluate the use of genetic and genomic data to delineate species.

\section{Results}

\section{Mitochondrial Gene Phylogeny}

In total, 34 individuals were sequenced for the mitochondrial NADH2 marker across 12 locations. Two phylogenetic analyses of the trimmed alignment sequence data (1044 bp) (maximum likelihood phylogenetic tree and median-joining haplotype network) showed similar clusterings of haplotypes. The phylogenetic tree indicated two major clades: (i) samples from Australia (WAU and SEQ), Papua New Guinea (PNG), Lombok (LMB), Muncar (MUN), west coast of Sumatra (WSA and WSS); and (ii) samples from South East Asia including Thailand (PHU), Malaysia (PAH) and Indonesia (BIN, WKL, WJV, SUL).

Within the first clade, samples from Australia and Papua New Guinea formed a distinct cluster (Australian region) separated from samples from the south coast of Indonesia (the Indian Ocean region). Within the second clade, samples from the Indo-Malay region (PAH, BIN, WKL and WJV) formed a cluster separated from South Sulawesi and Thailand samples (Fig. 2a). The mean pairwise genetic distances ( $d$ ) between Indo-Malay samples and the Australian region ranged from 0.0264 to 0.0462 , while the pairwise distances within the Indo-Malay region ranged from 0.0008 to 0.0229 (see Additional file 1). Specimens from the west coast of Sumatra were more genetically similar to Muncar and Lombok (southern Indonesia), although located closer geographically to the Indo-Malay region (see Fig. 1). 
The median-joining haplotype network showed fine-scale groupings of the 13 haplotypes, with two main haplogroups between samples from the Indo-Malay region and those from the Indian Ocean and Australian regions. Within the Indo-Malay grouping, samples from BIN, WKL, and PAH formed a large haplotype, separated from WJV by $0.2 \%$ of sequence divergence. While PHU, SUL, MUN and LMB, formed a sub-cluster of haplotypes. Samples from the west coast of Sumatra (WSA and WSS) formed a distinct haplotype, while Australia (WAU and SEQ) and Papua New Guinea (PNG) formed an Australian region cluster (Fig. 2b). The largest haplotype divergence (1.7-2.8\%) occurred between the Indo-Malay samples and those from the Australian region. Samples from the Indian Ocean region (WSA, WSS, MUN and LMB) formed distinctive haplotypes separated from the Australian region by $0.5-1.4 \%$. In contrast, samples from South Sulawesi (SUL) formed a different sub-cluster of the Indo-Malay haplotypes by $0.6-0.8 \%$.

\section{SNP Genotyping}

A total of 82,994 SNPs were detected from 148 individuals across 16 sampling locations. Filtering criteria resulted in the subsequent reduction of SNP loci to 6,099 SNP loci (see Additional file 2) that was used for the population structure and phylogenetic analyses. All individuals clearly grouped into their geographical regions. A PCoA based on axis 1 (38.5\% of the variation among individuals) and axis 2 (19.5\%) showed three main clusters for the C. punctatum-complex (Fig. 3a): the Indo-Malay region, the Australian region and the Indian Ocean region (LMB, WSA, WSS). However, axis 3 (9.6\%) showed a clear separation of LMB from the WSA-WSS group (Fig. 3b). Individuals from South Sulawesi (SUL) showed some separation from the Indo-Malay region. Separation of individuals from SEQ, and those from PNG and WAU was evident within the Australian region (Fig. 3a, b).

Pairwise $F_{S T}$ analyses resulted in significant structuring among locations but the magnitude of differentiation varied by several orders $\left(F_{S T}\right.$ values $\left.=0.001-0.876, P=0-0.1\right)$. Some locations within the Indo-Malay region (BIN, PAH and WKL) showed limited structuring among locations $\left(F_{S T} \leq 0.1, P>0.05\right)$. In contrast, other locations within the region (PHU, PER, WJV, EJV, EKL and SAB) showed strong population structure $\left(F_{S T} \leq 0.5, P<0.05\right)$. Conversely, samples from the west coast of Sumatra (WSA, WSS) and Lombok (LMB) showed distinct genetic divergence $\left(F_{S T}>0.5, P<0.05\right)$ from those within the Indo-Malay region and the Australian region (Fig. 4, Additional file 3).

\section{Phylogenetic Inferences}

There were no fixed differences among locations in the Indo-Malay region except for South Sulawesi (SUL), which showed minimal fixed differences of $1-3 \%$. The west coast of Sumatra (WSA) had fixed allele differences of $10-22 \%$ with all other sampling locations. A similar pattern was observed in individuals from Lombok (LMB), which differed from all other locations by $10-21 \%$. The Australian region differed from all other locations by $6-23 \%$ fixed differences but showed low fixed differences within the region (1-2\% fixed differences) (see Additional file 4).

Two amalgamation steps were undertaken based on fixed allele differences. Firstly, only locations with no fixed differences resulted in all individuals from the Indo-Malay region (BIN, PAH, PER, WKL, WJV, EJV, 
$E K L, S A B$, and PHU) being pooled into one group (called PUN). Few but no significant differences in each comparison $(p>0.05)$ combined South Sulawesi (SUL) with the Indo-Malay group (PUN) but Lombok (LMB) and the west coast of Sumatra (WSA, WSS) remained separated. Individuals from PNG and WAU grouped together with SEQ into the Australian region group. The final result was four group entities with absolute fixed-differences, and we designated them as four distinct operational taxonomic units (OTUs) (see Additional file 5). The distance tree generated from the Fitch-Margoliash distance analysis combined the west coast of Sumatra $\left(\mathrm{OTU}_{2}\right)$ and Lombok $\left(\mathrm{OTU}_{3}\right)$ into a single clade (Fig. 5).

The maximum-likelihood from RAXML analysis of 148 individuals with $381,018 \mathrm{bp}$ of concatenated SNP sequence revealed three distinct clades. Most individuals from the Indo-Malay region, with the exception of SUL, formed a clade, while LMB, WSA and WSS formed a separate clade (Fig. 6a). Although individuals from the Australian region occur in the same clade, individuals from SEQ were clearly separated from WAU and PNG in a longer branch (Fig. 6b).

\section{Species delimitation}

The Bayesian coalescent-based species tree derived from the SNAPP analysis divided C. punctatum into four distinct clades corresponding to the OTUs. Relationships among locations within clades remained consistent in all topologies (Fig. 7 and Additional file 6). The Bayes factor delimitation (BFD*) analysis supported the hypothesis to delimit $C$. punctatum into four putative species based on OTUs as the topranked model $(\mathrm{H}-5)$ with the estimate of the highest value of the marginal likelihood with a decisive Bayes factor $\left(2 \log _{e} B F>10\right)$ against the initial model $(H-1)(28)$ (Table 1$)$.

Table 1

The Bayes factor delimitation (BFD*) analysis for the five species delimitation models of Chiloscyllium punctatum with the rank based on the marginal likelihood estimates (MLE). Two models show positive Bayes factor (BF) against the initial model $\mathrm{H}-1$

\begin{tabular}{|llllc|}
\hline Model & Species & MLE & Rank & BF \\
\hline H-1: (Indo Malay + Indian Ocean) vs (Australian region) & 2 & - & 4 & - \\
\hline $\begin{array}{l}\text { H-2: (Indo Malay) vs (Indian Ocean + Australian } \\
\text { regions) }\end{array}$ & 2 & -43468.79 & 3 & -2695.58 \\
$\begin{array}{l}\text { H-3: (Indo Malay + Sumatra) vs (Lombok+ Australian } \\
\text { region) }\end{array}$ & 2 & -45849.86 & 5 & -2066.56 \\
$\begin{array}{l}\text { H-4: (Indo Malay) vs (Indian Ocean) vs (Australian } \\
\text { region) }\end{array}$ & 3 & -37765.24 & 2 & 14102.68 \\
\hline $\begin{array}{l}\text { H-5: (Indo Malay) vs (Sumatra) vs (Lombok) vs } \\
\text { (Australian region) }\end{array}$ & 4 & -35340.07 & 1 & 18953.01 \\
\hline
\end{tabular}

\section{Biological Characteristics}


Maximum $T L$ measurements from each location supported OTU $_{1}$ as different from the other OTUs (see Table 2) with all individuals from $\mathrm{OTU}_{1}$ reaching their maximum $T L$ at a smaller size $(<110 \mathrm{~cm} T L)$ compared with those from $\mathrm{OTU}_{2}, \mathrm{OTU}_{3}$ and $\mathrm{OTU}_{4}(>110 \mathrm{~cm} \mathrm{TL})$. Based on available references, $C$. punctatum attains maturity at $\leq 100 \mathrm{~cm} T L$, with individuals from Indo-Malay region (corresponding to $\left.\mathrm{OTU}_{1}\right)$ mature at around $67-70 \mathrm{~cm} T L(29,30)$, while those from Australia and PNG (corresponding to $\left.\mathrm{OTU}_{4}\right)$ mature at about $84-87 \mathrm{~cm} \mathrm{TL}(24,31)$. No information on size at maturity is available for the regions that fall within $\mathrm{OTU}_{2}$ and $\mathrm{OTU}_{3}$. Nevertheless, those biological features provide an indication of differences among OTUs that support the genetic findings. 
Table 2

Data relating to Chiloscyllium punctatum samples from the Indo-Australian region

\begin{tabular}{|c|c|c|c|c|c|c|}
\hline Location & Code & Country & Fishing ground & $n$ & $\begin{array}{l}T L \\
(\mathrm{~cm})\end{array}$ & $\begin{array}{l}\operatorname{Max} T L \\
(\mathrm{~cm})\end{array}$ \\
\hline Phuket & $\mathrm{PHU}$ & Thailand & $\begin{array}{l}\text { Andaman Sea, upper } \\
\text { Malacca Strait }\end{array}$ & $\begin{array}{l}9 \\
(3)\end{array}$ & $\begin{array}{l}47.2- \\
84.5\end{array}$ & $91^{1}$ \\
\hline Perak & PER & Malaysia & $\begin{array}{l}\text { West coast of Malaysian } \\
\text { Peninsular }\end{array}$ & $\begin{array}{l}11 \\
(-)\end{array}$ & $43-90$ & $100^{2}$ \\
\hline Pahang & PAH & Malaysia & $\begin{array}{l}\text { East coast of Malaysian } \\
\text { Peninsular }\end{array}$ & $\begin{array}{l}10 \\
(2)\end{array}$ & $47-83$ & $103^{2}$ \\
\hline Sabah & $S A B$ & Malaysia & North of Borneo & $\begin{array}{l}10 \\
(-)\end{array}$ & $\begin{array}{l}49.3- \\
98\end{array}$ & $105.6^{2}$ \\
\hline Bintan & BIN & Indonesia & Malacca Strait & $\begin{array}{l}10 \\
(3)\end{array}$ & $65-80$ & 80 \\
\hline $\begin{array}{l}\text { West } \\
\text { Kalimantan }\end{array}$ & WKL & Indonesia & $\begin{array}{l}\text { West coast of } \\
\text { Kalimantan }\end{array}$ & $\begin{array}{l}10 \\
(-)\end{array}$ & $70-95$ & $99^{3}$ \\
\hline Aceh & WSA & Indonesia & $\begin{array}{l}\text { Northwest coast of } \\
\text { Sumatra }\end{array}$ & $\begin{array}{l}8 \\
(4)\end{array}$ & $78-98$ & $146^{5}$ \\
\hline Sibolga & WSS & Indonesia & West coast of Sumatra & $\begin{array}{l}2 \\
(2)\end{array}$ & $\begin{array}{l}64.9- \\
71.6\end{array}$ & $113^{4}$ \\
\hline West Java & WJV & Indonesia & Seribu Islands waters & $\begin{array}{l}11 \\
(1)\end{array}$ & $36-83$ & $93^{3}$ \\
\hline East Java & EJV & Indonesia & Java Sea & $\begin{array}{l}10 \\
(-)\end{array}$ & $44-90$ & 90 \\
\hline East Kalimantan & EKL & Indonesia & East coast of Kalimantan & $\begin{array}{l}10 \\
(-)\end{array}$ & $52-92$ & 92 \\
\hline South Sulawesi & SUL & Indonesia & Southwest of Sulawesi & $\begin{array}{l}12 \\
(2)\end{array}$ & $50-90$ & $99^{3}$ \\
\hline Muncar & MUN & Indonesia & Bali Strait & (3) & $57-90$ & $105.5^{3}$ \\
\hline Lombok & LMB & Indonesia & Lombok Strait & $\begin{array}{l}16 \\
(7)\end{array}$ & $\begin{array}{l}80- \\
132\end{array}$ & $148^{3}$ \\
\hline South PNG & PNG & $\begin{array}{l}\text { Papua New } \\
\text { Guinea }\end{array}$ & Gulf of Papua & $\begin{array}{l}5 \\
(4)\end{array}$ & $32-81$ & $132^{7}$ \\
\hline $\begin{array}{l}\text { Western } \\
\text { Australia }\end{array}$ & WAU & Australia & West coast of Australia & $\begin{array}{l}1 \\
(1)\end{array}$ & 59 & $132^{7}$ \\
\hline
\end{tabular}

Data collected from: ${ }^{1}$ DoF Thailand; ${ }^{2}$ SEAFDEC; ${ }^{3} \mathrm{LIPI} ;{ }^{4}$ Dharmadi et al. (74); ${ }^{5} \mathrm{WCS}$ Indonesia; ${ }^{6}$ White et al. (31); ${ }^{7}$ Last and Stevens (24). All other samples collected as part of this study (2018-2019). $n=$ number of tissue samples analysed for SNPs and mtDNA (in parentheses); TL = total length; Max TL = recorded maximum TL from each location. 


\begin{tabular}{|c|c|c|c|c|c|c|}
\hline Location & Code & Country & Fishing ground & $n$ & $\begin{array}{l}T L \\
(\mathrm{~cm})\end{array}$ & $\begin{array}{l}\operatorname{Max} T L \\
(\mathrm{~cm})\end{array}$ \\
\hline $\begin{array}{l}\text { South East } \\
\text { Queensland }\end{array}$ & SEQ & Australia & Moreton Bay & $\begin{array}{l}13 \\
(3)\end{array}$ & $\begin{array}{l}62.2- \\
102.3\end{array}$ & $132^{7}$ \\
\hline \multicolumn{7}{|c|}{$\begin{array}{l}\text { Data collected from: }{ }^{1} \text { DoF Thailand; }{ }^{2} \text { SEAFDEC; }{ }^{3} \mathrm{LIPI} ;{ }^{4} \text { Dharmadi et al. }(74) ;{ }^{5} \mathrm{WCS} \text { Indonesia; }{ }^{6} \text { White } \\
\text { et al. (31); }{ }^{7} \text { Last and Stevens }(24) \text {. All other samples collected as part of this study }(2018-2019) . \mathrm{n}= \\
\text { number of tissue samples analysed for SNPs and mtDNA (in parentheses); TL = total length; Max TL } \\
=\text { recorded maximum TL from each location. }\end{array}$} \\
\hline
\end{tabular}

\section{Discussion}

\section{Species-Population Boundary}

Both mitochondrial DNA and genome-wide SNP data analysis support a species complex in the brownbanded bamboo shark. By sampling comprehensively across a part of its range, we have revealed greater genetic variation and potentially more species than suggested by a previous study (18) that included fewer sampling locations. Obtaining representative samples across a species' distributional area can be challenging for elasmobranchs. There are potential difficulties in obtaining a comprehensive sample set for a species, due to; rarity in nature or in markets; difficult to catch; financial cost; large specimen sizes; wide geographical spread and species protections, which limits access to samples or requires special permits (32). Still, many new species of elasmobranch have been described based on limited geographic sampling over the last decade (e.g. (33-35)).

Our analyses on the genetic data of Chiloscyllium punctatum support the hypothesis of Naylor et al. (18) that a potential cryptic species occurs in Australia. However, by including a more comprehensive suite of sampling sites that captured more genetic variation, we were able to identify four OTUs within $C$. punctatum. Yet, as the OTUs are allopatric, it is difficult to discern the population-species boundary on genetic data alone. Depending on the nature of the supporting information, $C$. punctatum species complex may consist of three or four putative species. Based on the genetic data alone, the four OTUs can be interpreted as four distinct species supported by both phylogenetic and species delineation (BFD*) analyses.

The type locality for the original description of $C$. punctatum was described from a geographic location associated with $\mathrm{OTU}_{1}$ in the waters off Jakarta, Indonesia (36). Specimens from Jakarta were clearly grouped in $\mathrm{OTU}_{1}$, which comprises individuals that inhabit shallow waters (20-50 m) within the IndoMalay Archipelago $(22,23)$. Individuals from $\mathrm{OTU}_{1}$ are not only genetically separated to those in the other OTUs, but the distinction is also supported by biological, ecological and geographical data. Individuals from $\mathrm{OTU}_{1}$ have a relatively smaller body size with the maximum $T L$ at around $1 \mathrm{~m}$, compared with other OTUs that have a maximum $T L$ more than $130 \mathrm{~cm}$ (see Table 2). That Indo-Malay individuals mature at a smaller size than do those from the Australasia further supports species delimitation $(24,27,30,31)$. However, no information on size at maturity is available for individuals from the Indian Ocean region 
$\left(\mathrm{OTU}_{2}\right.$ and $\left.\mathrm{OTU}_{3}\right)$ and given this biological feature is likely important for species delimitation in this group, further studies are needed. Ecologically, we observed that $C$. punctatum from the Indo-Malay region is commonly found on soft-bottom habitats (e.g. sand flat, muddy substrate). Geographically, all locations that were linked by shallow waters within the Sunda Shelf region (from Phuket, Thailand to East Kalimantan, Indonesia) showed strong connectivity except for South Sulawesi, which is geographically the furthest east location included in $\mathrm{OTU}_{1}$. South Sulawesi is also separated from the Indo-Malay region by a deep trench that could restrict gene flow.

Individuals from the Indian Ocean and Australian regions may be grouped into a putative species based on similarities of their biological characters, such as the larger maximum body size than for the IndoMalay region, or may be separated into two distinct species based on ecological and geographical perspectives. However, the BFD* analysis lent support to two separate groups. Therefore, individuals from Australian $\left(\mathrm{OTU}_{4}\right)$ and the Indian Ocean regions $\left(\mathrm{OTU}_{2}, \mathrm{OTU}_{3}\right)$ can be designated as an incipient species if there are any supportive morphological characters that can distinguish them.

In the Indian Ocean region, individuals from the west coast of Sumatra $\left(\mathrm{OTU}_{2}\right)$ were clearly separated from Lombok $\left(\mathrm{OTU}_{3}\right)$ based on their fixed allele differences. However, this may reflect population level difference, given continuity of habitat between their geographic locations in the outer margin of the Sunda Islands region. Further, the mtDNA phylogram grouped both locations in the same clade together with those from Muncar in the south of the Bali Strait (see Fig. 2a). The high fixed allele differences, $F_{S T}$ values and marked separation in the phylogenetic tree of specimens between Lombok and other locations may be caused by the unique geographical position of this location in the Lesser Sunda Island region. Lombok is separated from other locations by deep water (The Bali Sea and the Flores Sea in the north, and the Indian Ocean in the south, each with depths of ca. 1500-3000 m) and the strong Indonesian Throughflow current in the west (the Lombok Strait). Together, these likely represent significant barriers to gene flow between Lombok and both the Indo-Malay and the Australian regions. The geographical barrier in the Lombok Strait is an important feature for speciation in particular groups such as the separation of two blue-spotted maskray species, Neotrygon caeruleopunctata in the west and $N$. australie in the east $(37,38)$. In contrast, this barrier is just resulting in population structure for other species such as the Indonesian wobbegong, Orectolobus leptolineatus (33) and Indonesian speckled catshark, Halaelurus maculosus (39) that occur along the eastern Indian Ocean. Additional sampling at locations along the south coast of Java and the west coast of Sumatra is required to bridge the geographic gap that exists in our data between Sumatra and Lombok to further resolve whether the separation demonstrated here is representative of speciation or population differences. Nevertheless, in terms of habitat preference, $C$. punctatum from along the west coast of Sumatra, south of Java to Nusa Tenggara in eastern Indonesia (including Lombok), inhabit similar coral and rocky reef habitats.

The bamboo shark species from the Australian region $\left(\mathrm{OTU}_{4}\right)$ can be found in various habitats, including coral reefs, seagrass beds, mangroves and estuaries (24). The tectonic plate boundary between the Sahul Shelf (South PNG, Western Australia, and South East Queensland) and the Sunda Shelf (Greater and 
Lesser Sunda Islands) is considered a major barrier causing a genetic break that separates populations and potential species within this complex. Examples of the influence of this barrier on species level differences can be found in blackspot sharks and banded eagle rays $(40,41)$. Even though species in the Australian region formed a distinct clade, there are some fixed differences between specimens from South East Queensland and those from South PNG and Western Australia. Nevertheless, there is no physical barrier, such as deep water or strong currents that might be a driver of genetic segregation between these locations. Therefore, we suggest that locations in $\mathrm{OTU}_{4}$ represent a single species with population structure, and the differences within the clade may reflect a variation by distance effect (42). This should be further tested by intermittent sampling locations in northern Australian waters.

Our study also revealed that geographic distance does not directly correspond to genetic distance. For instance, Aceh $\left(\mathrm{OTU}_{2}\right)$ is separated from Phuket $\left(\mathrm{OTU}_{1}\right)$ by only about $470 \mathrm{~km}$ while some sites within the $\mathrm{OTU}_{1}$ cluster (such as between Phuket and West Java) are separated by more than three times the distance. Similarly, Muncar and East Java are separated by only $300 \mathrm{~km}$ and connected by the narrow and shallow waters of the Bali Strait, yet showed strong genetic separation. A possible reason for that separation is habitat type. In addition to the role that deep water and tectonic plate barriers play, habitat preferences are likely to be important in either structuring populations or delimiting species $(43,44)$. Based on habitat preferences, the four OTUs can be further delimited into three groups with $\mathrm{OTU}_{2}$ and $\mathrm{OTU}_{3}$ combined. The BFD* analysis also lent high support to this hypothesis.

The decision to delineate species complexes may vary among taxa. In some taxa, genetic differences may not be reciprocal with either morphology (phenotypic plasticity), biology (reproductive traits), or ecological characteristics (habitat preferences) (45). In elasmobranchs, genetics has been used to can delineate cryptic species in a species complexes in the genera Carcharhinus, Aetobatus and Neotrygon $(38,40,46,47)$, as well as coalesce two genera into one genus due to genetic indistinctiveness, such as in Mobula (48).

For some taxonomic groups such as birds and some mammals, the term 'subspecies' is used to define a population or group of populations that are distinctive yet insufficiently different to constitute a separate species based on subtleties in appearance and/or in genetic makeup (49-51). The term 'subspecies' is also used to differentiate a species complex based on ecological speciation for populations without multigene discontinuity (52). Moreover, 'subspecies' is applied to geographically isolated populations driven by biodiversity and conservation purposes, such as in some freshwater fishes (50). However, the use of subspecies in some taxa is not preferable due to confusion with the population term $(53,54)$, and has been rarely used in the past few decades for marine fishes (55). For elasmobranchs, this term has only been applied to few taxa, e.g. in catsharks (56-59), dogfishes (60), smooth-hounded sharks (61), hammerheads (62), eagle rays (63), and skates (64). Some of those subspecies remain valid such as the smooth-hounded shark (Mustelus canis canis and M. c. insularis) and for several species of skates (from Genus Raja and Leucoraja), while others were considered junior synonyms or have been elevated into 
distinct species (65). Therefore, the use of subspecies for the bamboo shark OTUs is plausible if they cannot be definitively classified at either the species or population level.

\section{Conservation implications of the species delimitation}

Splitting cryptic species in a complex into one or more distinct species may provide advantages for the species, not just for formal scientific recognition, but also to assess conservation risk $(3,4,6,66)$. Thus, from a conservation perspective, separating $C$. punctatum into two or three species is desirable as differences in biological features, spatial distribution, habitat occupancy, and type of fishery that operates in an area could influence how each species should be managed for sustainability. For instance, due to the intensive trawl operations in the Indo-Malay region $(26,67)$, the species based on OTU would be $^{2}$ subjected to higher fishing pressure than individuals within $\mathrm{OTU}_{2}$ and $\mathrm{OTU}_{3}$ where bottom longline fisheries operate due to unsuitable substrates for bottom trawling, and compared to $0 \mathrm{TU}_{4}$ where they are neither targeted nor caught as bycatch. This situation may lead to differences in threat profiles that necessitate revision among the OTUs of their conservation status.

In terms of fisheries management, each OTU with distinct fisheries characteristics can be treated separately. For instance, limits on minimum size or permitted fishing gear may differ between OTUs due to the nature of the fishery. For countries that implement ecosystem or species-based conservation management such as in Indonesia (referring to Regulation of the Minister of Forestry P.57/MenhutII/2008 and Regulation of the Minister of Marine Affairs and Fisheries 3/2010), regulating two different options of fisheries management for one species is challenging, compared with countries that implement conservation strategies on a population-basis. Therefore, splitting $C$. punctatum into at least two or three different species for management purposes is appropriate for countries that apply species-based management, as long as diagnostic morphological characters are available. Especially when they are marketed in the same place with a lack of traceability, as occurs in Indonesia.

In contrast, splitting a cryptic species complex into several species based purely on genetics can cause problems if there are no strong supportive diagnostic characters to differentiate them in the field. An example is in the Neotrygon kuhlii species complex $(38,68)$ where several species are sympatric yet cannot be diagnosed morphologically, which complicates management. Policymakers may find it difficult to implement conservation and management actions, especially if the species are sympatric, inhabit similar ecotypes, or occur in one fishing region. Without the ability to differentiate among the members of a complex, studies on their biology, ecology, or population stock for management purposes are rendered problematic due to the likelihood of misidentification and possibly overlapping information (37). This is particularly challenging in countries or regions where access to genetic analysis is still limited and costly (69-71).

\section{Conclusions}

Genetics is a powerful tool for detecting and differentiating cryptic species complexes; however, genetic differentiation that lacks supporting biological and ecological differentiators, may not be usefully applied 
to determine on which side of the population-species boundary a taxon falls. Genetic analyses from two populations of a relatively sedentary species that are separated by considerable geographical distance may show large fixed differences, supporting them being identified as separate species. In comparison, subsequent and sufficient sampling across the full range of the species complex would reveal any "intermediate" population, which would prevent bias in determining the efficacy of population versus species delimitation recommendations (72). Therefore, the use of genetics for delimiting species should include comprehensive sampling locations to identify populations that may bridge differences between two or more distinct populations before they are interpreted as separate species.

It has been proposed that guidelines be developed for the application of genomic data to justify taxonomic boundaries before delimiting species from cryptic complexes (12). Determining a new species based on genetic differences should be approached with caution and supported by strong justifications. We suggest some essential steps that should be taken before designating a distinct population or OTU derived from a genetic study to be a putative species. Firstly, it is important to ensure that sampling locations are representative across the range with consideration to their basic biological information (e.g., migratory or sedentary, pelagic or demersal), as speciation is likely occurring more often in species with low dispersal ability (73). Secondly, there should be diagnostic morphological character(s) that can be used to distinguish the new species from the former species and other OTUs. Third, there are supporting morphological, habitat or behavioural characteristics that can be used to confidently extirpate the new species from a species complex. Lastly, clear information on geographic range should be included within the description of the new species to avoid ambiguity for users, be they biologists, policymakers or managers, to allow them to conduct further studies and related conservation and fishery assessments. In relation to the Chiloscyllium punctatum species complex, we suggest that a taxonomic revision is warranted to enhance conservation and management strategies for the species that presently reside within it.

\section{Methods}

\section{Sampling and DNA extraction}

Tissue samples from Chiloscyllium punctatum were obtained from 17 localities within the IndoAustralian region (Table 2). Samples from Thailand, Malaysia, and Indonesia (Sumatra, Java, Kalimantan, South Sulawesi, and Lombok) were sourced from local fish markets. Samples were from Moreton Bay, eastern Australia, samples from Papua New Guinea and Western Australia were provided by the national fish collection (CSIRO, Hobart). The size of the largest specimen from each location was noted, either through direct measurement of total length $(T L)$ or derived from other sources of information (Table 2), as previous studies indicate that $C$. punctatum maximum body size may vary among locations $(22,27)$. Length at maturity data was sourced from published materials for this region $(24,29-31)$.

All tissue samples were extracted using the DNA salting out procedure (75). Total DNA concentration of each sample was measured using a Qubit 2.0 Fluorometer (Invitrogen, Carlsbad, CA, USA), with DNA 
extractions diluted to 50-150 ng. $\mathrm{ul}^{-1}$ for downstream processing.

\section{mtDNA phylogenetic analyses}

A total of 34 tissue samples collected from 12 locations during 2017 was analysed with the mtDNA gene marker NADH dehydrogenase subunit 2 (NADH2). Samples were amplified using MyTaq DNA polymerase (Bioline Reagents, London) and primers from Naylor et al.(18) with a modified forward primer: ILEM Chilo2 (5'- AAG GAT CAC TTT GAT AGA GT- 3'), and modified reverse primer: ASNM Chilo (5'- AAC ACT TAG CTG TTA ACT AA- $3^{\prime}$ ). Thermocycler conditions were set as follows: 3 min at $95^{\circ} \mathrm{C}$ for initial denaturation, 32 cycles of amplification $\left(30 \mathrm{~s}\right.$ at $95^{\circ} \mathrm{C}, 20 \mathrm{~s}$ at $52^{\circ} \mathrm{C}$, and $1 \mathrm{~min}$ at $72^{\circ} \mathrm{C}$ ), and a final extension for $10 \mathrm{~min}$ at $72^{\circ} \mathrm{C}$. Each $20 \mu \mathrm{l}$ reaction mixture contained $10 \mu \mathrm{l} \mathrm{MyTaq}, 2 \mu \mathrm{l}$ of each 10 pmol. $\mu \mathrm{l}^{-1}$ primer, $2 \mu \mathrm{l}$ of 100-150 ng. $\mu \mathrm{l}^{-1}$ template DNA, and $4 \mu \mathrm{ddH}_{2} \mathrm{O}$. Amplified products were analysed by electrophoresis ( $1 \%$ agarose gel with GelRed $\circledast$ stain) and checked using Syngene gel documentation system G:BOX F3 with GeneSys image acquisition software (Synoptics Group, Cambridge, UK). The PCR products were purified using ExoSAP-IT from USB (Cleveland, Ohio). Products were sequenced with ILEM Chilo2 and ND2 Batoid (5'- CAC TTY TGA TTA CCA GAA GT- 3') forward primers to extend the total read per individual to $>800 \mathrm{bp}$. Sequencing reactions were performed at the Australian Equine Genetics Research Centre (The University of Queensland) using Applied Biosystems BDT v3.1 chemicals and standard procedures in $20 \mu \mathrm{l}$ volumes and analysed with an Applied Biosystems 3730 DNA analyser.

Each chromatogram was visually checked and all sample sequences were aligned in Geneious Pro ${ }^{\circledR}$ v7.1.9 (Biomatters Ltd, Auckland, New Zealand), together with two reference sequences of $C$. punctatum from Genbank: GN2590 from Queensland (accession number JQ518745.1) and GN4446 from West Kalimantan (JQ519064.1). Modeltest analysis was used to estimate the best fit model of the nucleotide substitution for the mtDNA data set based on the lowest value of the Akaike Information Criterion (AIC) corrected for small sample size (76). A maximum-likelihood phylogenetic tree was constructed using the Tamura-Nei 1993 model with a discrete Gamma distribution $(\operatorname{TrN}+\mathrm{G})$ as the best model $(+\mathrm{G}$ parameter $=$ 0.3851). The analyses were run using PAUP* 4.0a163 (77). The tree topology was evaluated using the maximum likelihood heuristic search with ten random stepwise addition sequence replicates. Statistical support for branch nodes was evaluated by bootstrapping across 1000 replicates (78). The phylogenetic tree was constructed using Dendroscope 3 (79). Pairwise distances between sequences were calculated based on the $\operatorname{TrN}+\mathrm{G}$ model with 1000 bootstrap replicates using Mega version X (80). Haplotype networks were reconstructed to visualise the relationship among sequence data based on the medianjoining network (81) using the PopArt program (82).

\section{Next-generation Sequencing}

A total of 148 extracted DNA samples (50-150 ng. $\mathrm{\mu l}^{-1}$ ) were genotyped with the DArT-seq approach by Diversity Arrays Technologies (DArT Pty Ltd, Canberra, Australia) using standard protocols as described by Kilian et al. (83). A combination of methylation-sensitive restriction enzymes (Pstl and Sphl) was used to digest the total DNA and detect SNP variation. Around two million sequences per sample generated 
from DArT pipelines were fragmented to $69 \mathrm{bp}$ and then combined into clusters by the DArT clustering algorithm. The low-quality base and identical sequences were corrected and analysed by the DArT software (DArTsoft14) to produce candidate SNP markers. SNP markers were identified within each cluster by calculating parameters such as average and variance of sequencing depth, the average counts for each SNP allele and the call rate for each sequence across all samples $(83,84)$.

\section{SNPs Filtering and genotyping analyses}

The SNP data were filtered using the R package 'dartR' (85). Loci with $100 \%$ repeatability (repAvg $=1.0$ ) and without missing values (call rate $=1.0$ ) were retained for subsequent analysis. Monomorphic loci and secondary SNPs within loci were removed, the latter to reduce the possibility of linked fragments. SNP loci with $\leq 1 \%$ minor allele frequency were removed.

Principal coordinate analysis (PCoA) was used to visualise the data with the R package 'dartR' $(42,43)$. Pairwise $F_{S T}$ values between populations along with confidence intervals and p-value were calculated based on the method by Weir and Cockerham (87) using the function gl.fst.pop in the 'dartR' package.

Fixed-difference analysis was applied to the filtered SNP data to identify private alleles at a locus that were not shared among sample locations as a robust indication of lack of gene flow (85). Locations represented by fewer than five individuals were not included in the analysis as they may yield falsepositive results (88). Locations that had non-significant fixed differences were further amalgamated ( $p$ value $>0.05)$. The final amalgamated groups from the significant fixed differences were designated as putative operational taxonomic units (OTUs). Analyses were conducted using the functions gl.collapse.recursive and gl.collapse.pval in 'dartR' $(85,88)$.

A phylogeny of the amalgamated fixed-differences matrix was constructed using a Fitch-Margoliash distance analysis based on the Euclidean distance. The program was run in Phylip version 3.698 (http://evolution.genetics.washington.edu/phylip.html). The filtered SNP genotype data were converted into a nexus file and concatenated into a single sequence tag per individual. Maximum-likelihood based phylogeny was estimated with RAXML v.8.2.10 (89) using the GTRGAMMA model with 1000 bootstrap replicates. The analysis was conducted on the Tinaroo High-Performance Computer system of the University of Queensland by implementing $20 \mathrm{CPUs}$ for $18 \mathrm{~h}$. The consensus phylogenetic tree was constructed using Dendroscope v.3.6.3 (79).

A multispecies coalescent analysis was performed to examine the species delimitation using SNAPP (90) available in BEAST 2 (91). Specifically, we tested five different species delimitation hypotheses. The first three hypotheses tested for two putative species based on different geographic groupings: (1) an Indo Malay-Indian Ocean and Australian region species; (2) Indo-Malay and eastern Indian Ocean vs Australian region; and (3) Indo-Malay and west coast of Sumatra vs Lombok and Australian region. The fourth hypothesis tested for three putative species as informed by habitat preferences (Indo-Malay vs eastern Indian Ocean vs Australian region). Lastly, the fifth hypothesis tested for four putative species, based on OTUs identified by the fixed difference analysis. As SNAPP is computationally demanding, we 
ran the analysis on one randomly selected individual per location for $\mathrm{OTU}_{1}$ and two individuals per location for the other OTUs. We repeated the analysis three times with different individuals to ensure reproducibility. The SNAPP datasets were prepared in BEAUTi with each location assigned as separate taxon and run with Markov chain Monte Carlo (MCMC) run for 2 million iterations and 500,000 burn-in. We set a gamma prior distribution with alpha $=3$ and beta $=100$ for a prior mean of 0.03 theta to reflect $0.3 \%$ sequence divergence as the mean divergence among OTUs. The convergence of the MCMC was inspected in Tracer v.1.7.1. and the maximum clade credibility calculated using TreeAnnotator v.2.6.2.

The analysed tree set was visualised using DensiTree v. 2.2.7. (92). The Bayes factor delimitation method (BFD*) was implemented as a plug-in to BEAST 2 to compare marginal likelihood estimates (MLE) for alternative species delimitation models (93). We conducted a path sampling analysis of 50 steps (when the marginal likelihood estimate remained constant) with 500,000 MCMC iterations and burn-in of 50,000 iterations. The Bayes Factor (BF) was calculated by subtracting MLE values of two assigned models multiplying by two (93).

\section{Abbreviations}

AIC

Akaike information criterion

BEAST

Bayesian evolutionary analysis sampling trees

$\mathrm{BF}$

Bayes factors

BFD

Bayes factor delimitation

BIN

Bintan, Riau, Indonesia

CSIRO

Commonwealth Scientific and Industrial Research Organisation

DArT

Diversity Arrays Technologies

DNA

Deoxyribonucleic acid

DoF

Department of Fisheries

EJV

East Java, Indonesia

EKL

East Kalimantan

LIPI

Lembaga Ilmu Pengetahuan Indonesia 
LMB

Lombok, Indonesia

MCMC

Markov chain Monte Carlo

MLE

Marginal likelihood estimates

MUN

Muncar, Indonesia

mtDNA

Mitochondrial deoxyribonucleic acid

$\mathrm{NADH} 2$

nicotinamide adenine dinucleotide hydrogenase subunit 2

OTU

Operational taxonomic unit

$\mathrm{PAH}$

Pahang, Malaysia

PCoA

Principal coordinate analysis

PCR

Polymerase chain reaction

PER

Perak, Malaysia

$\mathrm{PHU}$

Phuket, Thailand

PNG

Papua New Guinea

RAXML

Randomized axelerated maximum likelihood

SAB

Sabah, Malaysia

SEAFDEC

Southeast Asian Fisheries Development Center

SEQ

Southeast Queensland, Australia

SNAPP

SNP and AFLP Package for Phylogenetic analysis

SNPs

Single nucleotide polymorphisms

SUL

South Sulawesi, Indonesia 
TL

Total length

$\mathrm{TrN}+\mathrm{G}$

Tamura-Nei 1993 model with a discrete Gamma distribution

WAU

Western Australia

WSA

Aceh, Indonesia

WSS

Sibolga, Indonesia

\section{Declarations}

Ethics approval and consent to participate

'Not applicable'

Consent for publication

'Not applicable'

Availability of data and materials

The datasets supporting the conclusions of this article are available in the Dryad repository, https://doi.org/10.5061/dryad.rbnzs7h89.

Competing interests

The authors declare no competing interests.

\section{Funding}

Funding was provided by RCO LIPI for specimen collection in Indonesia and the Winifred Violet Scott Charitable Trust grant (JLP:uc:sco-4.289).

\section{Authors' Contributions}

F and CLD conceived and designed the study; F performed data analyses, generated the graphs and wrote the manuscript; CLD, IRT and MBB revised the manuscript. All authors read and approved the final manuscript.

Acknowledgments

We thank Ahmad Ali (MFRDMD), Tassapon Krajangdara (DoF Thailand), Selvia Oktaviyani, Johan Picasouw and Asep Rasyidin of RCO LIPI, Ranny Yuneni (WWF), Benaya Simeon (WCS), Mursida 
(BPSPL), Arnault Gauthier (UQ), William White (CSIRO) and Galih Rakasiwi for assistance in collecting tissue samples; the RCC team of UQ for assistance with the HPC facility.

\section{References}

1. Li C, Corrigan S, Yang L, Straube N, Harris M, Hofreiter M, et al. DNA capture reveals transoceanic gene flow in endangered river sharks. Proc Natl Acad Sci U S A. 2015;112(43):13302-7.

2. Pall-Gergely B. Should we describe genera without molecular phylogenies? Zootaxa. 2017;4232(4):593-6.

3. Fišer C, Robinson CT, Malard F. Cryptic species as a window into the paradigm shift of the species concept. Mol Ecol. 2018;27(3):613-35.

4. Beheregaray LB, Caccone A. Cryptic biodiversity in a changing world. J Biol. 2007;6(4):9-.

5. de Queiroz K. Species concepts and species delimitation. Syst Biol. 2007;56(6):879-86.

6. Bickford D, Lohman DJ, Sodhi NS, Ng PKL, Meier R, Winker K, et al. Cryptic species as a window on diversity and conservation. Trends Ecol Evol. 2006;22(3):148-55.

7. Feckler A, Schulz R, Bundschuh M. Cryptic lineages-same but different? Integr Environ Assess Manage. 2013;9(1):172-3.

8. Freudenstein JV, Broe MB, Folk RA, Sinn BT. Biodiversity and the species concept - Lineages are not enough. Syst Biol. 2017;66(4):644-56.

9. Struck TH, Feder JL, Bendiksby M, Birkeland S, Cerca J, Gusarov VI, et al. Finding evolutionary processes hidden in cryptic species. Trends Ecol Evol. 2018;33(3):153-63.

10. Sukumaran J, Knowles LL. Multispecies coalescent delimits structure, not species. Proceedings of the National Academy of Sciences. 2017;114(7):1607.

11. Carstens BC, Pelletier TA, Reid NM, Satler JD. How to fail at species delimitation. Mol Ecol. 2013;22(17):4369-83.

12. Coates DJ, Byrne M, Moritz C. Genetic diversity and conservation units: Dealing with the speciespopulation continuum in the age of genomics. Frontiers in Ecology and Evolution. 2018;6(165).

13. Cook LG, Edwards RD, Crisp MD, Hardy NB. Need morphology always be required for new species descriptions? Invertebr Syst. 2010;24(3):322-6.

14. Frankham R, Ballou JD, Dudash MR, Eldridge MDB, Fenster CB, Lacy RC, et al. Implications of different species concepts for conserving biodiversity. Biol Conserv. 2012;153:25-31.

15. Stanton DWG, Frandsen P, Waples RK, Heller R, Russo I-RM, Orozco-terWengel PA, et al. More grist for the mill? Species delimitation in the genomic era and its implications for conservation. Conserv Genet. 2019;20(1):101-13.

16. Zachos FE, Apollonio M, Bärmann EV, Festa-Bianchet M, Göhlich U, Habel JC, et al. Species inflation and taxonomic artefacts-A critical comment on recent trends in mammalian classification. Mamm Biol. 2013;78(1):1-6. 
17. Knowlton N. Sibling species in the sea. Annual Review of Ecology, Evolution, and Systematics. 1993;24:189-216.

18. Naylor GJP, Caira JN, Jensen K, Rosana KAM, White WT, Last PR. A DNA sequence-based approach to the identification of shark and ray species and its implications for global elasmobranch diversity and parasitology. Bull Am Mus Nat Hist. 2012;367:1-262.

19. Naylor GJP, Caira JN, Jensen K, Rosana KAM, Straube N, Lakner C. Elasmobranch phylogeny: A mitochondrial estimate based on 595 species. In: Carrier JC, Musick JA, Heithaus MR, editors. Biology of Sharks and Their Relatives, Second Edition. Boca Raton, FL: CRC Press; 2012. p. 31-56.

20. Hosegood J, Humble E, Ogden R, de Bruyn M, Creer S, Stevens G, et al. Genome-wide data for effective conservation of manta and devil ray species. bioRxiv. 2019:458141.

21. Compagno LJV. Sharks. In: Fischer W, Bianchi G, editors. FAO species identification sheets for fishery purposes Western Indian Ocean; (Fishing Area 51) Prepared and printed with the support of the Danish International Development Agency (DANIDA). 1-6. Rome: Food and Agricultural Organization of the United Nations; 1984.

22. Compagno LJV. Species catalogue for fishery purpose. Sharks of the world an annotated and illustrated catalogue of sharks species known to date. Bullhead, mackerel and carpet sharks (Heterodontiformes, Lamniformes and Orectolobiformes). Rome: FAO; 2001. 269 p.

23. Compagno LJV, Dando M, Fowler SL. Sharks of the world. New Jersey: Princeton University Press; 2005. $368 \mathrm{p}$.

24. Last PR, Stevens JD. Sharks and Rays of Australia. 2 ed. Victoria: CSIRO Publishing; 2009. 644 p.

25. Compagno LJV. FAO species catalogue. Sharks of the world. An annotated and illustrated catalogue of sharks species known to date. Part 1: Hexancathiformes to Lamniformes. Rome: FAO; 1984. 1-249 p.

26. Arai T, Azri A. Diversity, occurrence and conservation of sharks in the southern South China Sea. PLoS ONE. 2019;14(3):e0213864.

27. Dharmadi, Fahmi, White WT. Species composition and aspects of the biology of Orectolobiformes from Indonesian waters. J Fish Biol. 2015;86(2):484-92.

28. Kass RE, Raftery AE. Bayes Factors. Journal of the American Statistical Association. 1995;90(430):773-95.

29. White WT, Last PR, Stevens JD, Yearsley GK, Fahmi, Dharmadi. Economically important sharks and rays of Indonesia. Canberra: Australian Centre for International Agricultural Research; 2006. 329 p.

30. Yano K, Ahmad A, Gambang AC, Idris AH, Solahuddin AR, Aznan Z. Sharks and Rays of Malaysia and Brunei Darussalam. Kuala Trengganu: Southeast Asian Fisheries Development Center; 2005. 557 p.

31. White WT, Baje I, Sabub B, Appleyard SA, Pogonosky JJ, Mana RR. Sharks and rays of Papua New Guinea. Canberra: Australian Centre for International Agricultural Research; 2017. 327 p.

32. Heupel MR, Simpfendorfer A. Science or slaughter: Need for lethal sampling of sharks. Conserv Biol. 2010;24(5):1212-8. 
33. Last PR, Pogonoski JJ, White WT. A new wobbegong shark, Orectolobus leptolineatus sp. nov. (Orectolobiformes: Orectolobidae), from the Western Central Pacific. In: Last Peter R, White WT, Pogonoski JJ, editors. Descriptions of new sharks and rays from Borneo. Hobart: CSIRO Marine and Atmospheric Research Paper No. 32; 2010. p. 1-16.

34. Last PR, White WT. Two new stingrays (Chondrichthyes: Dasyatidae) from the eastern Indonesian Archipelago. Zootaxa. 2013;3722(1):1-21.

35. Last PR, White WT, Naylor G. Three new stingrays (Myliobatiformes: Dasyatidae) from the Indo-West Pacific. Zootaxa. 2016;4147(4):377-402.

36. Dingerkus G, DeFino TC. A revision of the orectolobiform shark family Hemiscyllidae. Bull Am Mus Nat Hist. 1983;176(1):1-94.

37. Last PR, White WT, deCarvalho MR, Seret B, Stehmann MFW, Naylor GJP, et al. Rays of the World. Clayton, Vic.: CSIRO Publishing; 2016. 800 p.

38. Last PR, White WT, Seret B. Taxonomic status of maskrays of the Neotrygon kuhlii species complex (Myliobatoidei: Dasyatidae) with the description of three new species from the Indo-West Pacific. Zootaxa. 2016;4083(4):533-61.

39. White WT, Last PR, Stevens JD. Halaelurus maculosus n. sp. and H. sellus n. sp., two new species of catshark (Carcharhiniformes: Scyliorhinidae) from the Indo-West Pacific. Zootaxa. 2007;1639:1-21.

40. White WT. A redescription of Carcharhinus dussumieri and $C$. sealei, with resurrection of $C$. coatesi and C. tjutjot as valid species (Chondrichthyes: Carcharhinidae). Zootaxa. 2012;3241:1-34.

41. White WT, Last PR, Baje L. Aetomylaeus caeruleofasciatus, a new species of eagle ray (Myliobatiformes: Myliobatidae) from northern Australia and New Guinea. Ichthyol Res. 2016;63(1):94-109.

42. Hindley JA, Graham BA, Pulgarin-R PC, Burg TM. The influence of latitude, geographic distance, and habitat discontinuities on genetic variation in a high latitude montane species. Scientific Reports. 2018;8(1):11846.

43. Fields AT, Feldheim KA, Gelsleichter J, Pfoertner C, Chapman DD. Population structure and cryptic speciation in bonnethead sharks Sphyrna tiburo in the south-eastern U.S.A. and Caribbean. J Fish Biol. 2016;89(5):2219-33.

44. Espíndola A, Ruffley M, Smith ML, Carstens B, Tank D, Sullivan J. Identifying cryptic diversity with predictive phylogeography. Proceedings of the Royal Society B: Biological Sciences. 2016;283:20161529.

45. Knowlton N. Molecular genetic analyses of species boundaries in the sea. Hydrobiologia. 2000;420:73-90.

46. Pavan-Kumar A, Kumar R, Pitale P, Shen K-N, Borsa P. Neotrygon indica sp. nov., the Indian Ocean blue-spotted maskray (Myliobatoidei, Dasyatidae). C R Biol. 2018;341(2):120-30.

47. White WT, Furumitsu K, Yamaguchi A. A new species of eagle ray Aetobatus narutobiei from the Northwest Pacific: An example of the critical role taxonomy plays in fisheries and ecological sciences. PLoS ONE. 2014;8(12):e83785. 
48. White WT, Corrigan S, Yang L, Henderson AC, Bazinet AL, Swofford DL, et al. Phylogeny of the manta and devilrays (Chondrichthyes: mobulidae), with an updated taxonomic arrangement for the family. Zool J Linn Soc. 2017;182(1):50-75.

49. Isaac NJB, Mallet J, Mace GM. Taxonomic inflation: its influence on macroecology and conservation. Trends Ecol Evol. 2004;19(9):464-9.

50. Nelson JS. Editorial and introduction: The species concept in fish biology. Rev Fish Biol Fish. $1999 ; 9(4): 277-80$.

51. Fennessy J, Bidon T, Reuss F, Kumar V, Elkan P, Nilsson Maria A, et al. Multi-locus analyses reveal four giraffe species instead of one. Curr Biol. 2016;26(18):2543-9.

52. Richardson BJ. Subspecies definitions and legislation: from eastern wallaroo (Osphranter robustus robustus) to euro (Osphranter robustus erubescens). Aust Mammal. 2019;41(1):65-75.

53. Froese R. The good, the bad, and the ugly: A critical look at species and their institutions from a user's perspective. Rev Fish Biol Fish. 1999;9(4):375-8.

54. Kullander SO. Fish species - how and why. Rev Fish Biol Fish. 1999;9(4):325-52.

55. Eschmeyer WN, Fricke R, Fong JD, Polack DA. Marine fish diversity: history of knowledge and discovery (Pisces). Zootaxa. 2010;2525:19-50.

56. Konstantinou H, McEachran JD, Woolley JB. The systematics and reproductive biology of the Galeus arae subspecific complex (Chondrichthyes: Scyliorhinidae). Environ Biol Fishes. 2000;57(2):117-29.

57. Springer S. A revision of the catsharks, Family Scyliorhinidae. USA: U.S. Department of Commerce; 1979.

58. Soares KDA, De Carvalho MR. The catshark genus Scyliorhinus (Chondrichthyes:

Carcharhiniformes:Scyliorhinidae): taxonomy, morphology and distribution. Zootaxa. 2019;4601(1):1-147.

59. Springer S, Sadowsky V. Subspecies of the western Atlantic catshark, Scyliorhinus retifer. Proceedings of the Biological Society Washington. 1970;83(7):83-98.

60. Myagkov NA, Kondyurin VV. Dogfishes, Squalus (Squalidae) of the Atlantic Ocean and comparative notes on the species of this genus from other regions. J Ichthyol. 1986;26(6):1-18.

61. Heemstra PC. A review of the smooth-hound sharks (genus Mustelus, family Triakidae) of the western Atlantic Ocean, with descriptions of two new species and a new subspecies. Bull Mar Sci. 1970;60:894-928.

62. Lim DD, Motta P, Mara K, Martin AP. Phylogeny of hammerhead sharks (Family Sphyrnidae) inferred from mitochondrial and nuclear genes. Mol Phylogen Evol. 2010;55(2):572-9.

63. Richards VP, Henning M, Witzell W, Shivji MS. Species delineation and evolutionary history of the globally distributed spotted eagle ray (Aetobatus narinari). J Hered. 2009;100(3):273-83.

64. Last PR, Weigmann S, Yang L. Changes to the nomenclature of the skates (Chondrichthyes: Rajiformes). In: Last PR, White WT, de Carvalho MR, Séret B, Stehmann MFW, Naylor GJP, editors. Rays of the world. Melbourne: CSIRO Publishing; 2016. p. 11-34. 
65. Weigmann S. Annotated checklist of the living sharks, batoids and chimaeras (Chondrichthyes) of the world, with a focus on biogeographical diversity. J Fish Biol. 2016;88(3):837-1037.

66. Lee MSY, Palci A. Morphological phylogenetics in the genomic age. Curr Biol. 2015;25:922-9.

67. Arunrugstichai S, True JD, White WT. Catch composition and aspects of the biology of sharks caught by Thai commercial fisheries in the Andaman Sea. J Fish Biol. 2018;92(5):1487-504.

68. Borsa P, Arlyza IS, Hoareau TB, Shen KN. Diagnostic description and geographic distribution of four new cryptic species of the blue-spotted maskray species complex (Myliobatoidei: Dasyatidae; Neotrygon spp.) based on DNA sequences. Journal of Oceanology and Limnology. 2018;36(3):82741.

69. Khan S, Nabi G, Ullah MW, Yousaf M, Manan S, Siddique R, et al. Overview on the role of advance genomics in conservation biology of endangered species. Int J Genomics. 2016;2016:3460416-.

70. Ndebele P, Musesengwa R. Will developing countries benefit from their participation in genetics research? Malawi Med J. 2008;20(2):67-9.

71. Padial JM, De la Riva I. Taxonomic Inflation and the Stability of Species Lists: The Perils of Ostrich's Behavior. Syst Biol. 2006;55(5):859-67.

72. Niemiller ML, Near TJ, Fitzpatrick BM. Delimiting species using multilocus data: Diagnosing cryptic diversity in the southern cavefish, Typhlichthys subterraneus (Teleostei: Amblyopsidae). Evolution. 2012;66(3):846-66.

73. Pinheiro HT, Bernardi G, Simon T, Joyeux J, Macieira RM, Gasparini JL, et al. Island biogeography of marine organisms. Nature. 2017;549(7670):82-5D.

74. Dharmadi, Mahiswara, Kasim K. Catch composition and some biological aspects of sharks in western Sumatera waters of Indonesia. Indonesian Fisheries Research Journal. 2016;22(2):99-108.

75. Sunnucks P, Hales DF. Numerous transposed sequences of mitochondrial cytochrome oxidase I-II in aphids of the genus Sitobion (Hemiptera: Aphididae). Mol Biol Evol. 1996;13:510-24.

76. Posada D, Crandall KA. Modeltest: testing the model of DNA substitution. Bioinformatics. 1998;14:817-8.

77. Swofford DL. PAUP*. Phylogenetic Analysis Using Parsimony (* and other methods). Version 4.0a163. Sunderland, Massachusetts: Sinauer Associates; 2017. 500 p.

78. Felsenstein J. Confidence limits on phylogenies: an approach using the bootstrap. Evolution. 1985; 39:783-91.

79. Huson DH, Scornavacca C. Dendroscope 3: An interactive tool for rooted phylogenetic trees and networks. Syst Biol. 2012;61(6):1061-7.

80. Kumar S, Stecher G, Li M, Knyaz C, Tamura K. MEGA X: Molecular Evolutionary Genetics Analysis across computing platforms. Mol Biol Evol. 2018;35:1547-9.

81. Bandelt HJ, Forster P, Röhl A. Median-joining networks for inferring intraspecific phylogenies. Mol Biol Evol. 1999;16(1):37-48. 
82. Leigh JW, Bryant D. Popart: full-feature software for haplotype network construction. Methods Ecol Evol. 2015;6(9):1110-6.

83. Kilian A, Wenzl P, Huttner E, Carling J, Xia L, Blois H, et al. Diversity Arrays Technology: A generic genome profiling technology on open platforms. In: Pompanon F, Bonin A, editors. Data production and analysis in population genomics: Methods and protocols. Totowa, NJ: Humana Press; 2012. p. 67-89.

84. Georges A, Gruber B, Pauly GB, White D, Adams M, Young MJ, et al. Genomewide SNP markers breathe new life into phylogeography and species delimitation for the problematic short-necked turtles (Chelidae: Emydura) of eastern Australia. Mol Ecol. 2018;27(24):5195-213.

85. Gruber B, Unmack PJ, Berry OF, Georges A. DARTr: An R package to facilitate analysis of SNP data generated from reduced representation genome sequencing. Molecular Ecology Resource. 2017;18:691-9.

86. Gower JC. Some distance properties of latent root and vector methods used in multivariate analysis. Biometrika. 1966;53(3-4):325-38.

87. Weir BS, Cockerham CC. Estimating F-statistics for the analysis of population structure. Evolution. 1984;38(6):1358-70.

88. Unmack PJ, Young MJ, Gruber B, White D, Kilian A, Zhang X, et al. Phylogeography and species delimitation of Cherax destructor (Decapoda: Parastacidae) using genome-wide SNPs. Mar Freshw Res. 2019;70(6):857-69.

89. Stamatakis A. RAxML version 8: a tool for phylogenetic analysis and post-analysis of large phylogenies. Bioinformatics. 2014;30(9):1312-3.

90. Bryant D, Bouckaert R, Felsenstein J, Rosenberg NA, RoyChoudhury A. Inferring species trees directly from biallelic genetic markers: bypassing gene trees in a full coalescent analysis. Mol Biol Evol. 2012;29(8):1917-32.

91. Bouckaert R, Heled J, Kühnert D, Vaughan T, Wu C-H, Xie D, et al. BEAST 2: A Software Platform for Bayesian Evolutionary Analysis. PLoS Comp Biol. 2014;10(4):e1003537.

92. Bouckaert R, Vaughan TG, Barido-Sottani J, Duchêne S, Fourment M, Gavryushkina A, et al. BEAST 2.5: An advanced software platform for Bayesian evolutionary analysis. PLoS Comp Biol. 2019;15(4):e1006650.

93. Leaché AD, Fujita MK, Minin VN, Bouckaert RR. Species delimitation using genome-wide SNP data. Syst Biol. 2014;63(4):534-42.

\section{Figures}




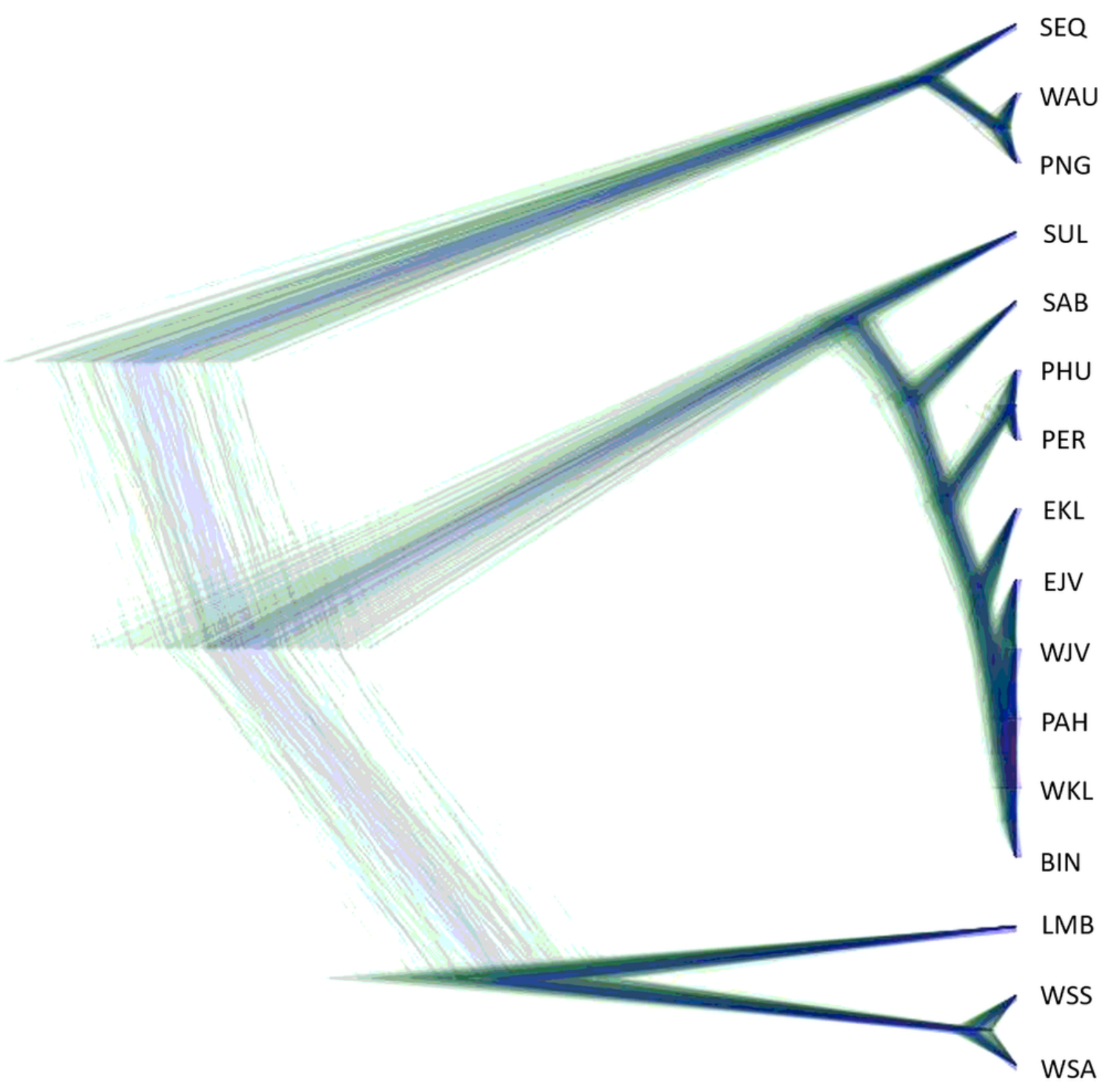

\section{Figure 1}

The species trees of 20 individuals representing 16 sampling locations from SNAPP analysis taken from every 1000 steps of the total 2,000,000 iterations, visualised by DensiTree software. 

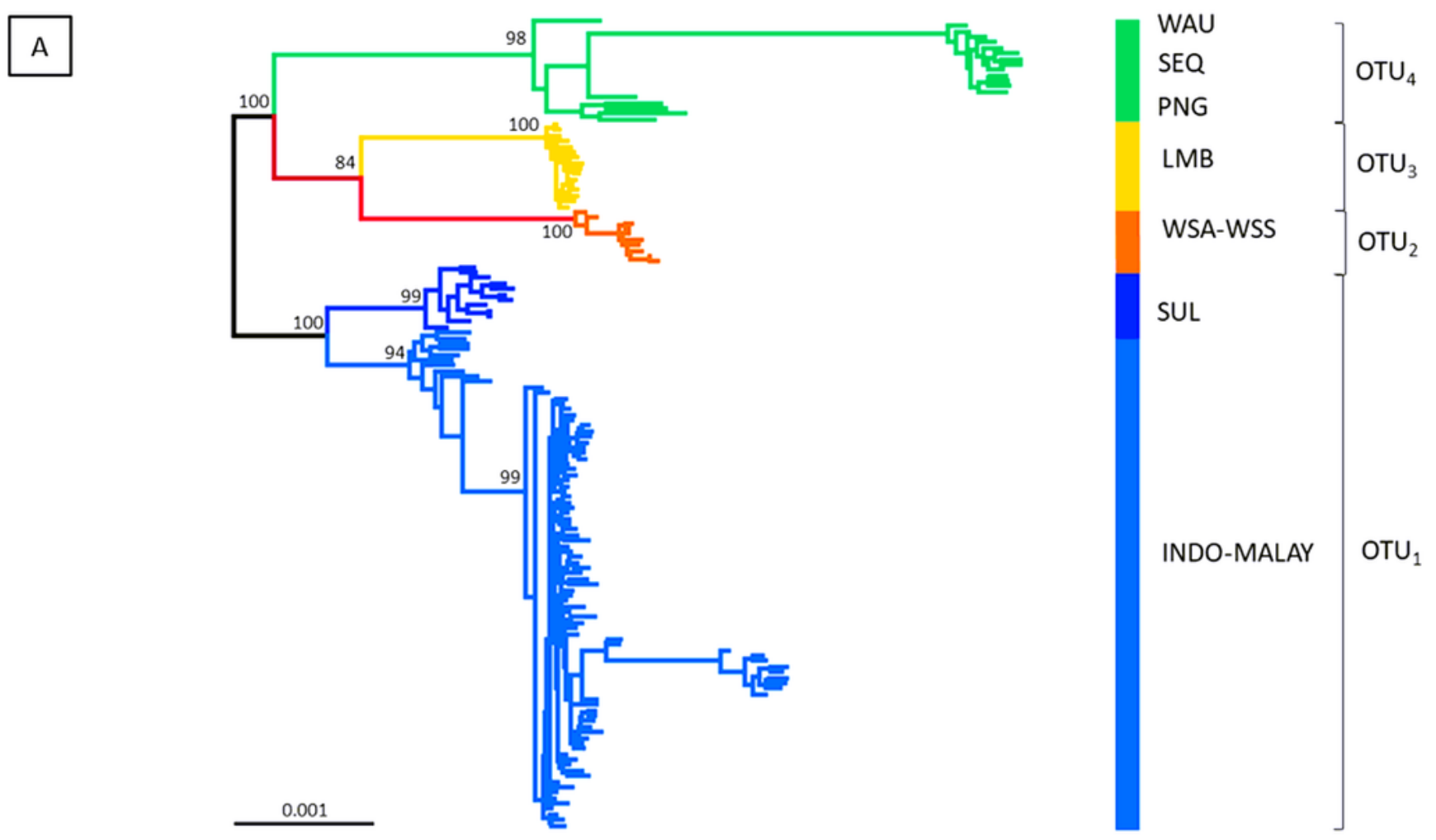

\section{B}

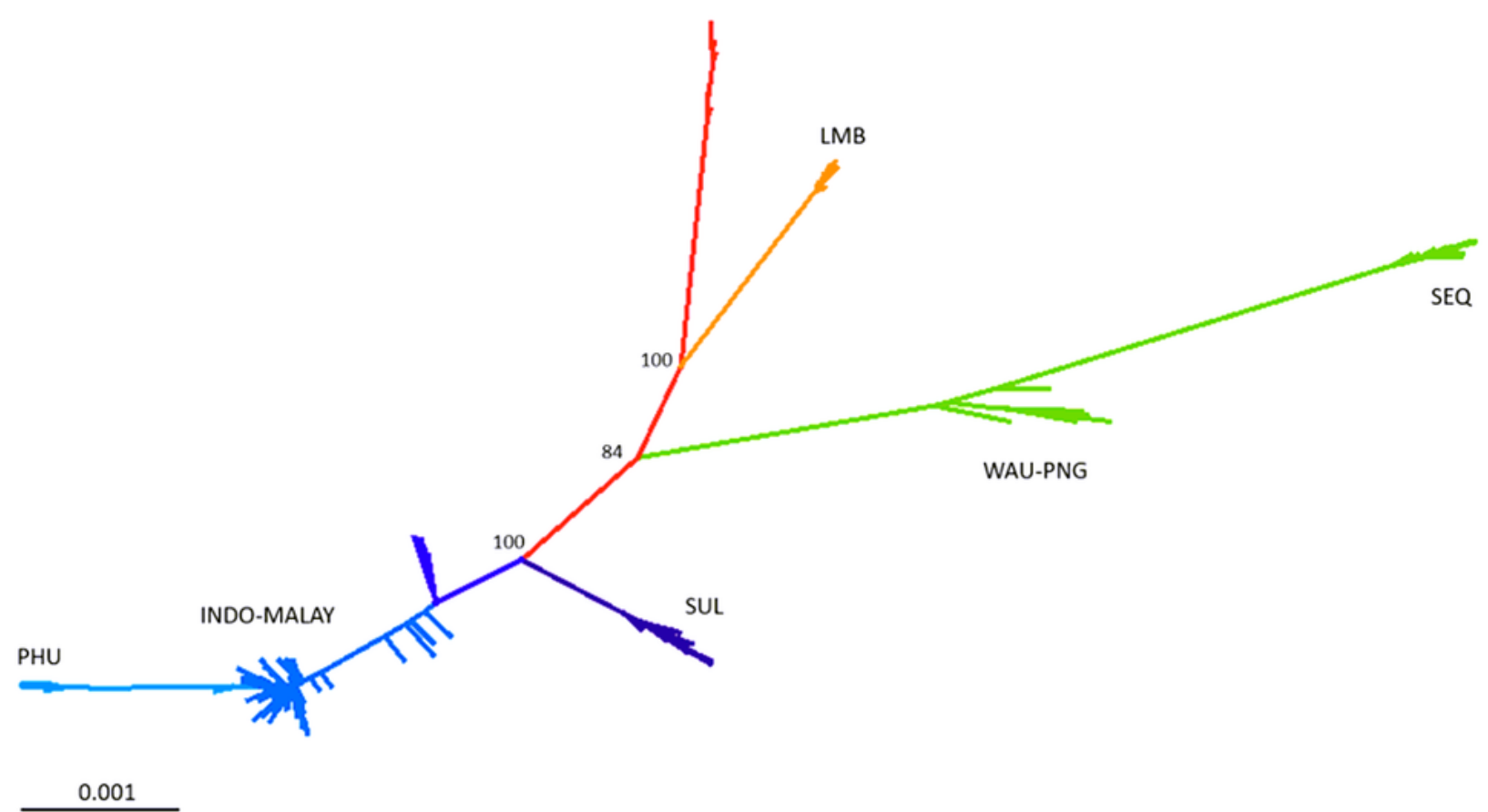

\section{Figure 1}

Phylogenetic tree of Chiloscyllium punctatum inferred from the concatenated sequence fragments of 6099 SNPs data using RAXML based on (a) maximum-likelihood tree; (b) a radial phylogram. Numbers on branches represent bootstrap values from 1000 replicates. Only bootstrap values of $80 \%$ or higher are presented. 


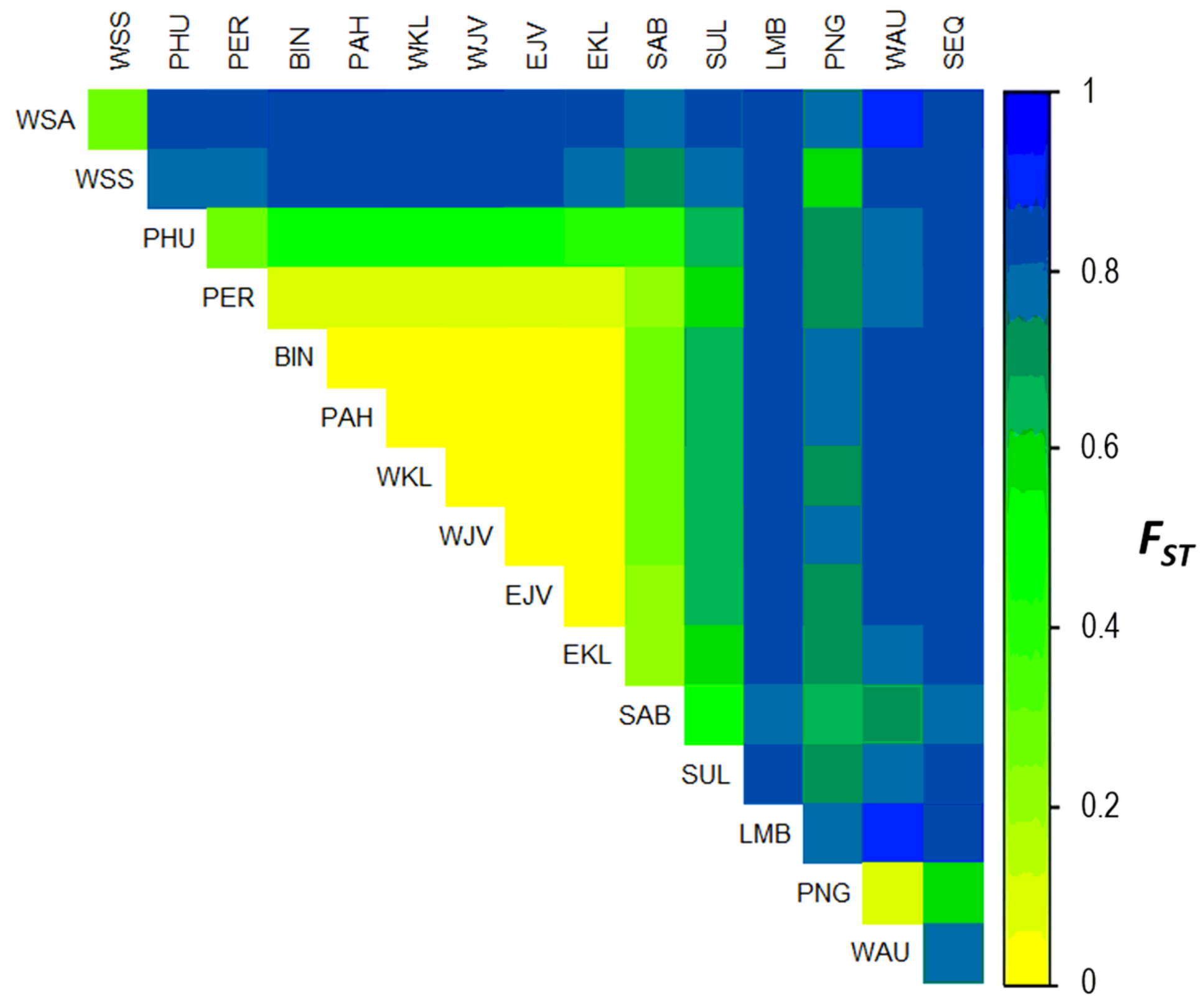

Figure 1

The pairwise FST values among locations based on SNP data. 

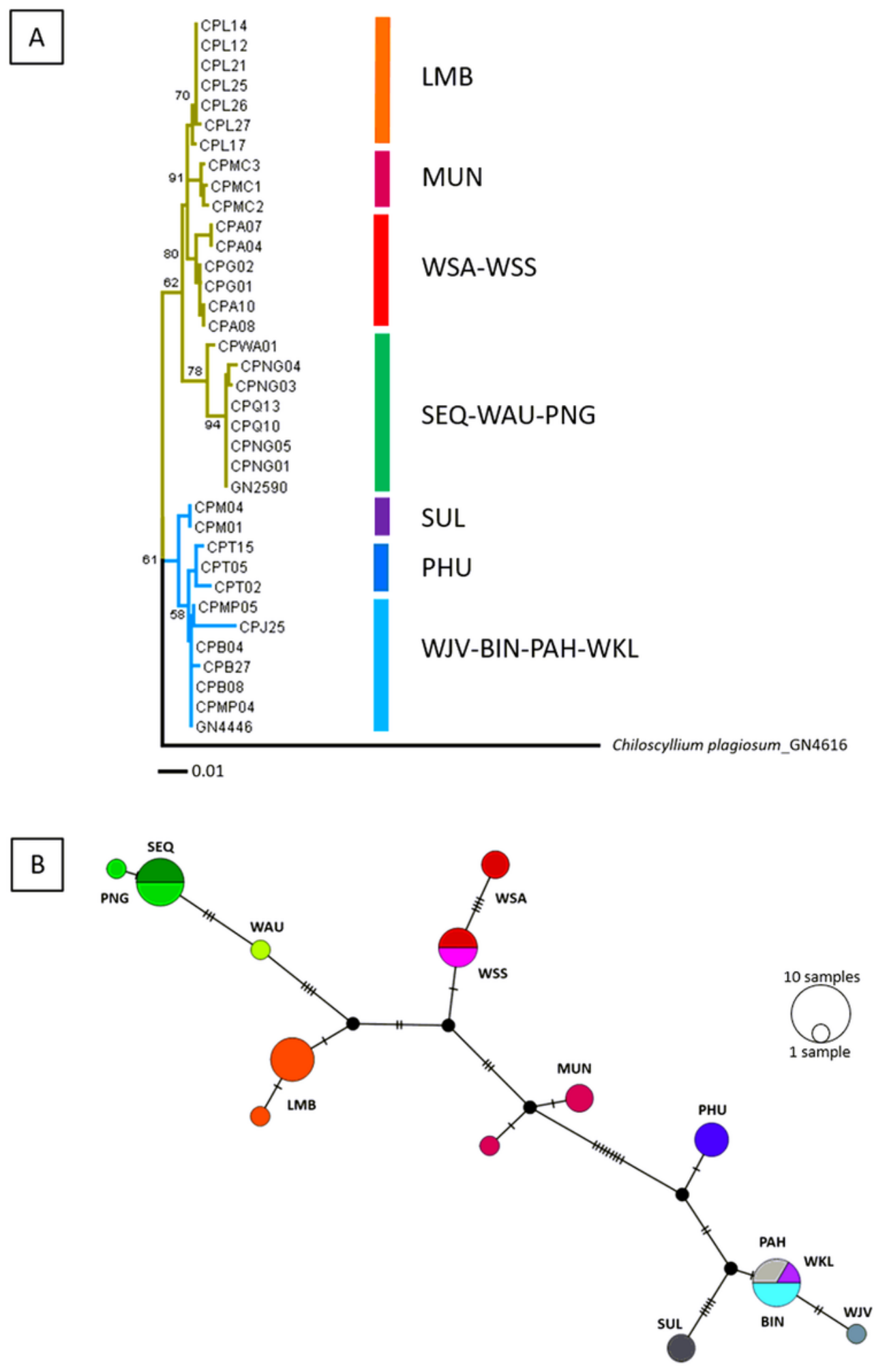

\section{Figure 1}

(a) Maximum likelihood (ML) tree based on the Tamura-Nei model analysis $(T N 93+G)$ of the NADH2 data with bootstrap support for 1000 replicates. The outgroup is the congener species, Chiloscyllium plagiosum from West Kalimantan; (b) Median-joining haplotype network of Chiloscyllium punctatum from Indo Australian region. Circle diameter represents haplotype frequency, connecting lines represent single mutational steps, and hash marks represent the number of haplotypes. 
SUL

100

\section{Figure 1}

Unrooted phylogenetic tree of four putative OTUs of C. punctatum based on Fitch-Margoliash maximum likelihood inferred from fixed allele difference analysis. Scale bar represents the number of allele differences.

A

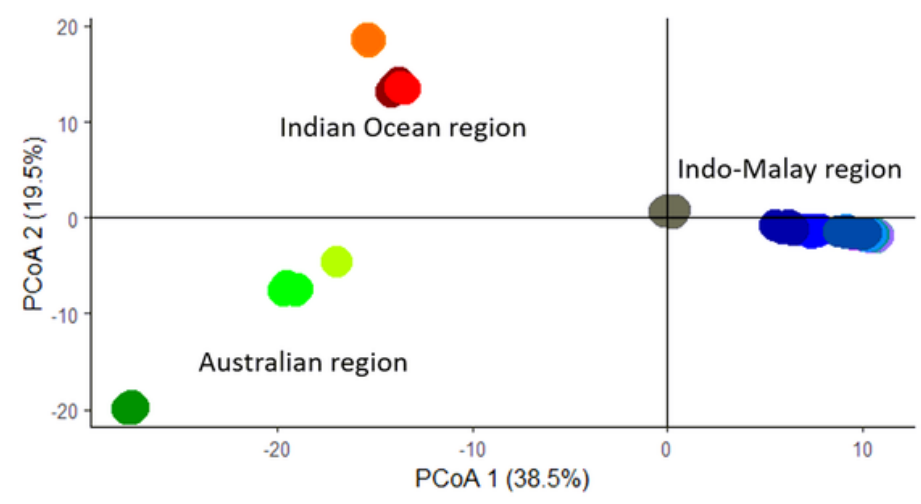

B

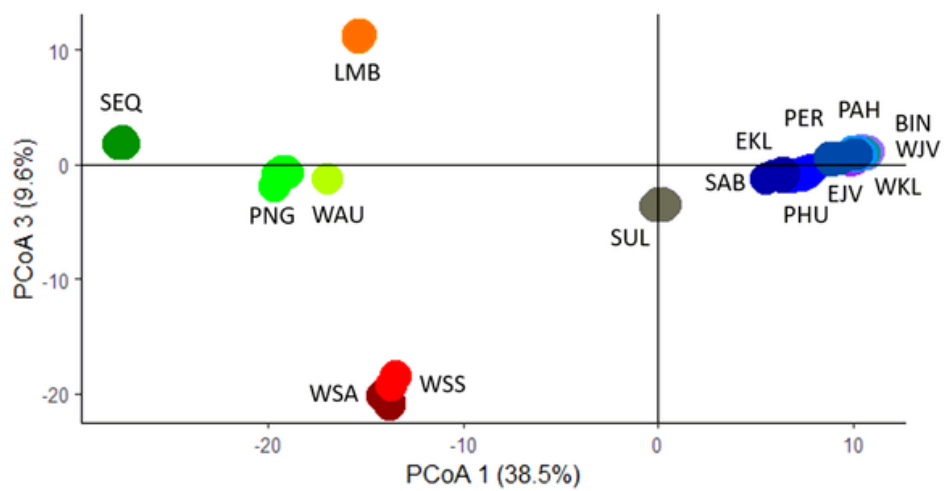

Figure 1

Principal Coordinate Analysis plots of Chiloscyllium punctatum from the Indo-Australian region of 6,099 SNPs based on: (a) axis 1 vs axis 2 , and (b) axis 1 vs axis 3 . 


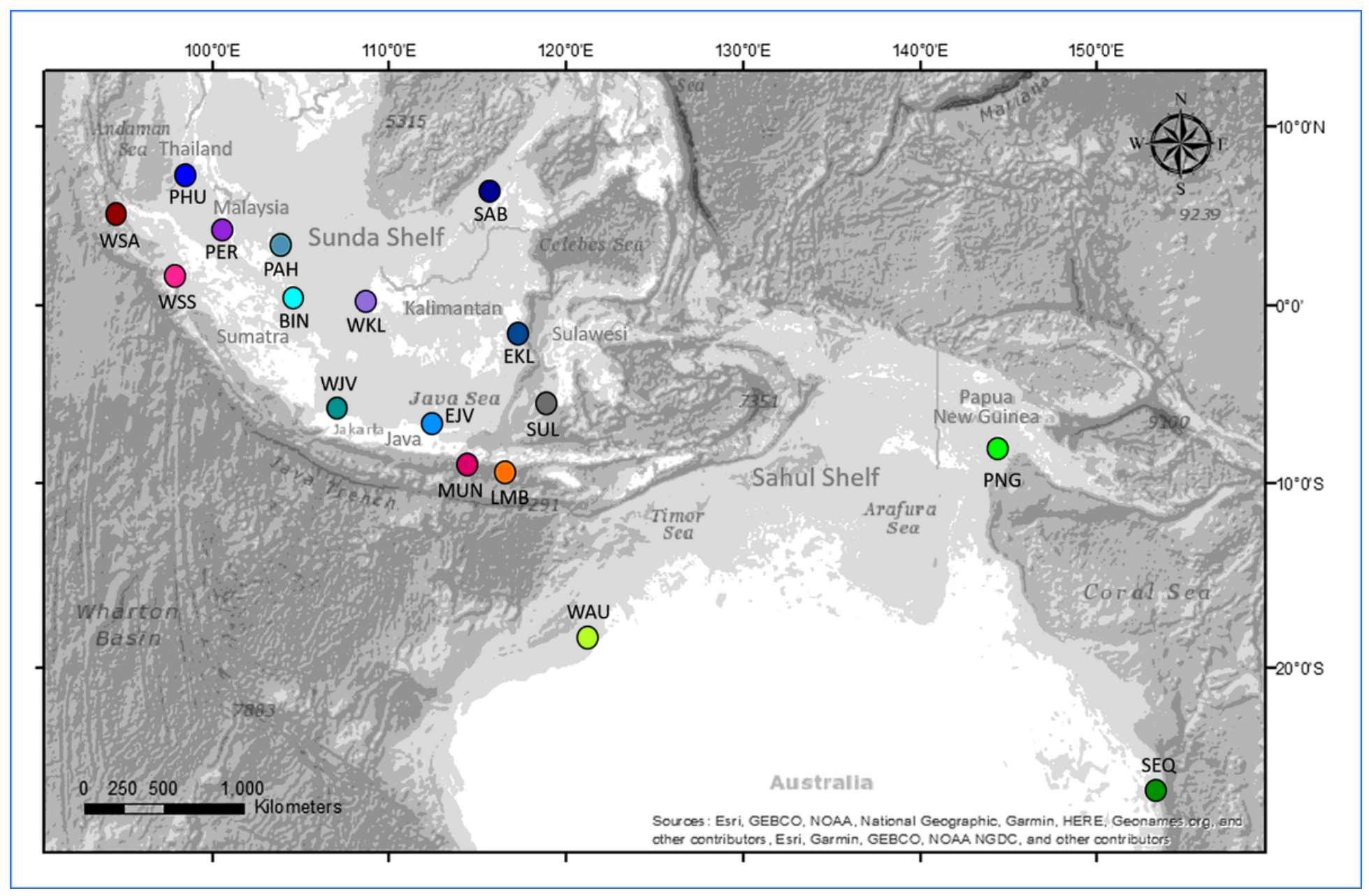

Figure 1

Map showing the Chiloscyllium punctatum sample-collection locations. Note: The designations employed and the presentation of the material on this map do not imply the expression of any opinion whatsoever on the part of Research Square concerning the legal status of any country, territory, city or area or of its authorities, or concerning the delimitation of its frontiers or boundaries. This map has been provided by the authors.

\section{Supplementary Files}

This is a list of supplementary files associated with this preprint. Click to download.

- Additionalfile4.doc

- Additionalfile1.doc

- Additionalfile3.doc

- Additionalfile6.doc

- Additionalfile2.doc

- Additionalfile5.doc 